顎下腺原発基底細胞腺癌例

坪田大·北秀明 ·渡邊 一正・藤沢 泰憲*

\title{
Basal Cell Adenocarcinoma of the Submandibular Gland
}

\author{
-A Rare Case of Malignancy of the Major Salivary Gland- \\ Hiroshi Tsubota, Hideaki Kita and Kazumasa Watanabe \\ (Sapporo Medical University) \\ Yasunori Fujisawa \\ (Muroran City General Hospital)
}

\begin{abstract}
Basal cell adenocarcinoma, a new type of malignant tumor, was added to the classification of a salivary gland tumor by WHO in 1991 . Most cases develop in major salivary glands, especially parotid glands.

We report here a case of basal cell adenocarcinoma which developed in the submandibular gland of a 52 year-old man. A pathological diagnosis was based upon Haematoxylin-Eosin staining and immunohistochemistry. The specimen was obtained from total resection of the submandibular gland and upper neck dissection. The patient has survived for 3 years after operation without any signs of local recurrence of regional or distant lymph node metastasis.

Clitical points at pathological diagnosis were also discussed.
\end{abstract}

Key words : basal cell adenocarcinoma, salivary gland tumor, immunohistochemistry

\section{はじめに}

顎下腺に発生する腫瘍として, 良性腫瘍では多型腺腫, 悪性腫瘍では腺癌, 腺様懹胞癌などが多く認められるこ とが知られている.今回我々は, 顎下腺腫瘍としてはき わめてまれとされる基底細胞腺癌の症例を経験した. 文 献的考察も含め, この症例につき検討したので報告する.

\section{症 例}

症例は54歳の男性で, 職業は一般事務職である. 既往 歴, 家族歴に特記すべきことはなく, 飲酒, 契煙の習慣 はない. 数カ月前から左㖽下部に小さな腫瘤を自覚し, 縮小傾向を認めないため平成 7 年12月 27 日当科外来を受 診した。

初診時, 触診上径 $15 \mathrm{~mm}$ の固い小腫瘤を顎下腺表面
にふれるとともに，䫇下腺自体も右嵿下腺に比べて固 かった．皮膚との瘉着はなく，皮膚表面にも変化は認め ず，圧痛を伴わなかった。

造影剤でのショックの既往があるためプレインCTを 撮影した. 左顎下腺は一様に描出され, 外側に触診上の 小腫瘤に相当すると思われるやや低吸収域を示す凸部を 認めた(図 1 , 矢印)。皮膚や下顎骨への浸潤は認められ ず，頸部リンパ節の腫大も認められない。

一般検血, 血液生化学検査には異常を認めず, 血清ア ミラーゼの上昇も認められなかった。. ${ }^{67} \mathrm{Ga}$ 执よび ${ }^{99 \mathrm{~m} T \mathrm{Tc}}$ シンチグラムでは, 異常な取り込みや欠損は認められな かった.

以上の結果より, 腫瘍あるいは炎症性疾患かとの診断 を得ることができず, 組織学的診断を行う目的で, 平成 


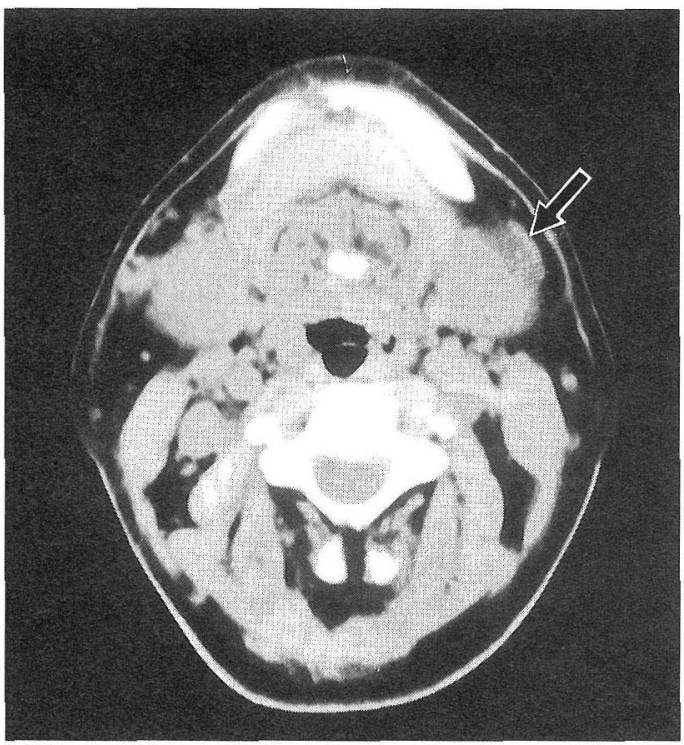

図 1 症例の顎下腺部造影 CT 写真

8 年 1 月 11 日, 局所麻醉下に顎下腺外側の小腫瘤を含め た楔状切除を施行，病理学的な検討を行い，覀性腫瘍の 可能性が高いとの診断のもとに根治手術を行うこととし た。

平成 8 年 2 月 29 日, 顎下腺全摘, 叔よび顎二腹筋前腹, 下顎骨，内頸静脈に团まれた組織の切除，すなわち上頸 部リンパ節の廓清を行った。

切除標本の病理学的検索の結果, 顎下腺原発の基底細 胞腺癌との診断がつけられた。

患者は, 以後定期的な外来受診, 胸部レントゲン撮影 等で経過を観察されているが，術後 3 年間で，局所再発 招よびリンパ節転移，遠隔転移は認められていない。

\section{病理組織学的検討}

はじめに行った生検で得られた材料のへマトキシリン 一エオジン染色像（図 2 ) では悪性腫瘍を疑ったものの, 基底細胞腺癌との診断には達していない。

切除標本の全体に浸潤する腫瘍細胞が認められる。腫 瘍細胞は比較的小型，核/細胞質比が高く，核異型を認 める。そして，大小の充実性胞巣を形成し，腺腔形成や 扁平上皮への分化傾向は認められない，粘液産生像は全 く認められないが, 腫瘍胞巣内にはPAS（過ヨウ素酸 シック法)強陽性の基底膜様物質が含まれている。これ らの所見から，腺様囊胞癌严るいは未分化癌を疑らが，

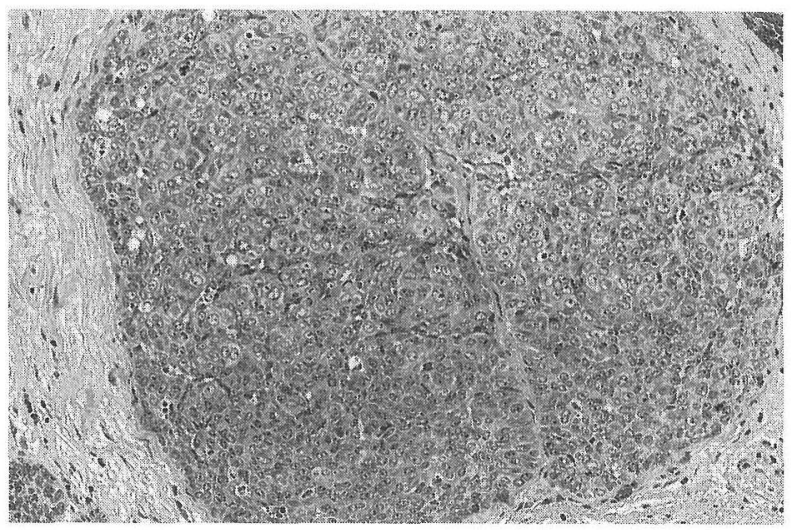

図 2 生検材料のヘマトキシリンーエオジン染色像 (200倍)

典型的な穊板構造や粘液産生像が認められないことから， 未分化小細胞癌の可能性が高いと考光られるというのが 生検標本に対する病理学的見解であった。

根治術に扝ける切除標本のへマトキシリンーエオジン 染色像（図 3 )では，小型から中型の多角形の腫瘍細胞が 大小の充実性集塊を形成して括り，被膜形成を認めず， 腫瘍細胞は周囲の唾液腺組織内と小胞巣を形成しつつ浸 潤増殖している，集塊辺縁の腫瘍細胞は小型で核濃縮し たものが著明であり，核の柵状配列も認められる。

免疫組織化学的には, 多くの腫瘍細胞が S-100 蛋白, サイトケラチン陽性であり，集塊内部には，癌胎児性蛋 白 (CEA) p上皮膜抗原 (epithelial membrane antigen; EMA) 陽性の細胞が管状に配列する，微少管形成を示 す所見を認めた（図 4，5）。好酸性，PAS 強陽性の基底 膜様物質が腫瘍胞巣内，招よびその周辺に多く認められ る.

以上の所見に基づき，その細胞構築，浸潤形式からは 未分化癌は否定的であり, solid type の basal cell adenocarcinoma（基底細胞腺癌）と診断された。

\section{考察}

基底細胞腺癌とは，1967年 Kleinsasser ら 提唱された基底細胞腺腫 (basal cell adenoma)なる組織 型に基づき，組織型はこの腺腫に似るが，浸潤性増殖を 示し，悪性とみなされる腫瘍として，1991年，WHO そ よって睡液腺腫瘍新分類に加光られたものである2).

Ellis ら゙による，29例に基づいた包括的な報告では， 全て成人に認められ，そのピークは60歳台に㐫り，性差 は洼とんど認められず，29例中の 24 例が耳下腺原発であ 

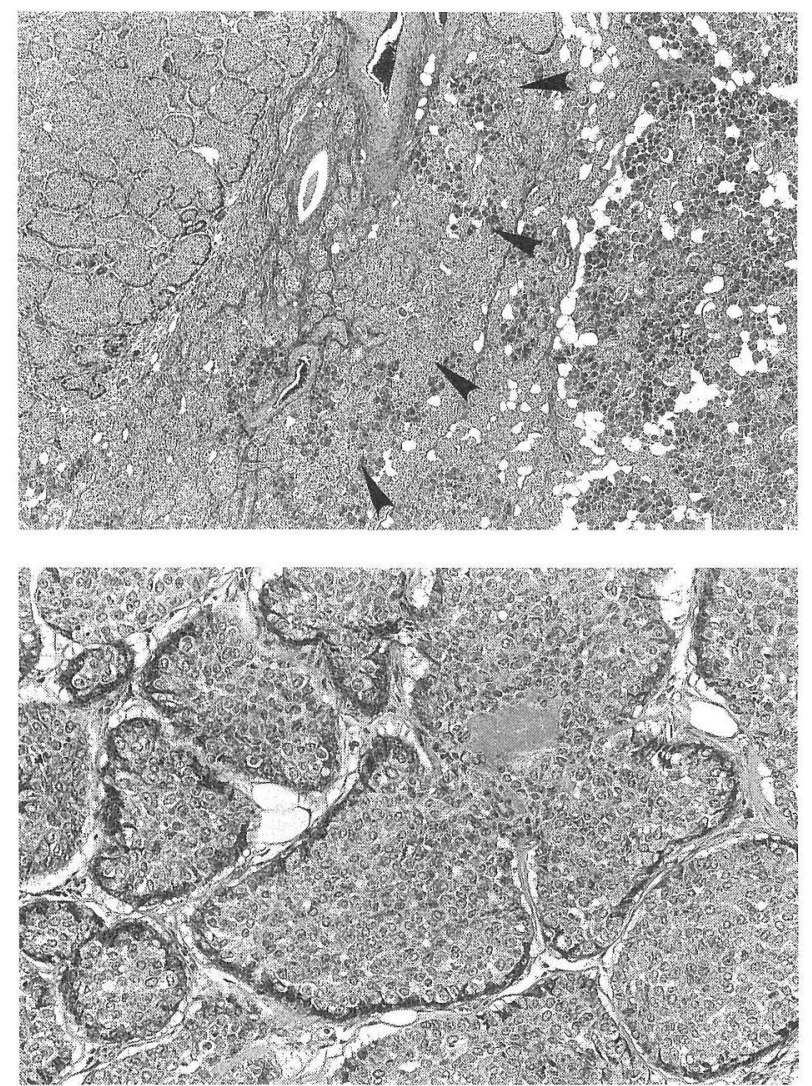

図 3 根治術による摘出標本のへマトキシリンーエオジン染色 像

上 : 40倍 ; 基底細胞様類円形細胞の充実性胞巣の増殖上 りなる腫瘍であり，周囲正常唾液腺との境界は被膜 がなく，浸潤性辺縁を示している(矢頭).

下：200倍；腫場細胞巣の辺緑には核の濃縮した萎縮細 胞が取り囲み, 胞巣内には硝子様物質が認められる. 明らかな腺管形成像はみられない。

り，頓部，頓粘膜原発が各 1 例，そして顎下腺に発生し たものは 3 例であった。

本邦に特ける報告例は，文献拈よび学会報告から筆者 が渉䍀し得た範囲では, 表 1 にまとめたように本症例を 含めて13例であり，顎下腺原発のものとしては本症例が 2 例目であった4) 13)。また，WHOの新分類が啇用され る以前に，悪性腫瘍の性格を示す基底細胞腺腫として報 告された本邦第 1 例は，1973年の大島ら ${ }^{14)}$ とる顎下 部腫瘤の例であり，その他表 2 に示すように，計 3 例の 報告がある14) 16)，

組織学的に，基底細胞腺癌のそれは基底細胞腺腫に似 る。すなわら，基底細胞腺腫において認好らるように，

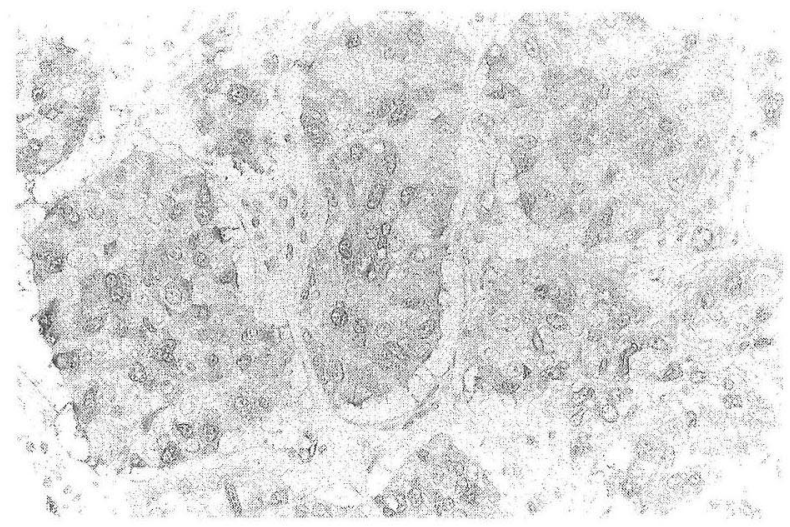

図 4 S-100 蛋白免疫染色像 (400倍)

腫瘍細胞の大部分は細胞質执よび核に弱陽性から中等度 陽性に染色される。

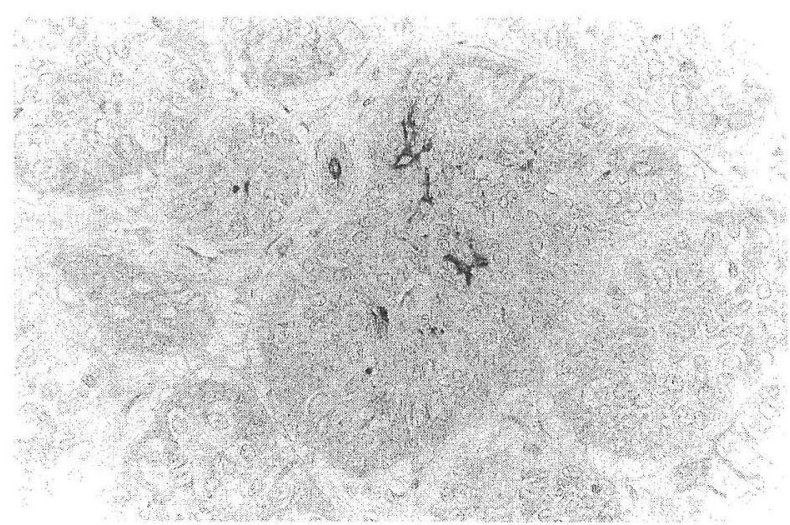

図 5 EMA 免疫染色像 (400倍)

腫瘍細胞の大部分は epithelial membrane antigen (EMA) 陰性であるが，胞巣内の所々に点状，線状，小管状に陽 性を示し，腺上皮への分化の傾向を示す。

ほぼ同様な形態をもつ一様な基底細胞様の外観を有する 細胞からなる。なた，同時に細胞質に乏しく濃染した核 をもつ円形から楕円形の小型の細胞と，それより大きく， 多角形で細胞質は好酸性であり，核が薄く染まる細胞と の，2 種類の上皮細胞を含えでいる場合がある.ささら PAS 陽性の硝子様の基底膜様物質がしばしば存在す る3117).

基底細胞腺腫と同様，主として細胞構築に基づいて， 基底細胞腺癌は次の 4 型に分類されている。すなわち， solid, trabecular, tubular, そして membranous の 4 亜

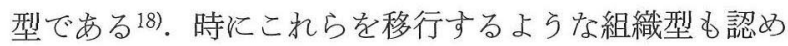


表 1 本邦に扝ける, 唾液腺原発基底細胞腺癌症例

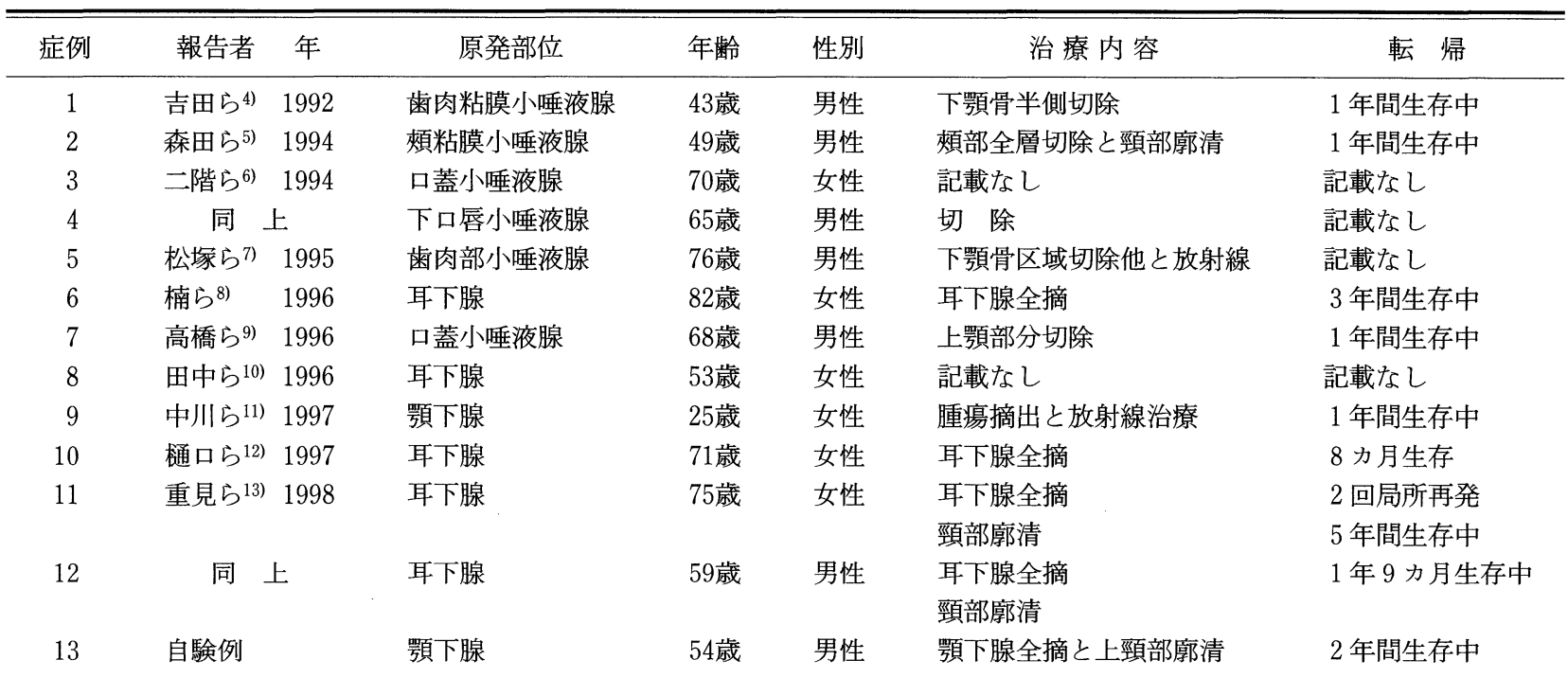

表 2 本邦に拉ける，悪性を示す基底細胞腺腫としての報告例

\begin{tabular}{|c|c|c|c|c|c|c|c|c|}
\hline 症例 & 報告者 & 年 & 原発部位 & 年齢 & 性別 & 治療内容 & 転 & 㷌 \\
\hline 1 & 大島ら ${ }^{14)}$ & 1973 & 顎下部 & 66歳 & 男性 & 腫瘍摘出と頸部廓清 & \multirow{2}{*}{\multicolumn{2}{|c|}{$\begin{array}{l}\text { 頭蓋底拉よび肺転移にて } 2 \text { 年後死亡 } \\
\text { 術後 } 6 \text { 力月生存 }\end{array}$}} \\
\hline 2 & 楊ら15) & 1983 & 口腔底小唾液腺 & 51歳 & 女性 & 腫瘤摘出術 & & \\
\hline 3 & 片桐ら $5^{16)}$ & 1989 & 上咽頭小唾液腺 & 73歳 & 女性 & 放射線治療と腫瘤摘出 & \multicolumn{2}{|l|}{ 不明 } \\
\hline
\end{tabular}

られるが，亜型の決定は，そのなかで優勢なパターンに 基づいて行われる. Ellis ら3) の報告では solid type が最 も多く29例中の19例であった。

基底細胞腺癌が基底細胞腺腫と異なる点は, それが浸 潤性増殖をすることにある。この増殖パターンは，基底 細胞腺腫に扣いてしばしば認められる，多胞巣性あるい は結節性の増殖と明らかに異なるところである。しかし， こらした浸潤性増殖を示すにもにもかかわらず, 細胞異 型や核異型は必ずしも目立たない。

免疫組織化学的診断は, 未分化小細胞癌と基底細胞腺 癌との鑑別に用いられることがある．基底細胞腺腫と基 底細胞腺癌とではその免疫組織化学的特徵はほ注同一で あり，腺管上皮や筋上皮への分化を示して，いずれもサ イトケラチン, CEA，㸬よび S-100 蛋白が陽性である. また腺上皮への分化を表す EMA や MFG (milk fat globule) 陽性の場合もある ${ }^{19)}$. これに対し未分化小細胞癌 では筋上皮や腺上皮への分化を示すことはない，逆に未 分化小細胞癌には，基底細胞腺癌には認められることの ない神経内分泌マーカーが陽性となることがある。
今回の症例に颃いて組織学的診断のポイントとなった のは，基底細胞様の腫瘍細胞が小胞巣を形成しつつ漫潤 性に増殖し，PAS 強陽性の基底膜様物質を認めている ことで,さらに免疫組織化学的には, サイトケラチン, CEA，EMA，S-100 蛋白が陽性であることが基底細胞腺 癌の特徵によく一致していた.こうした免疫組織化学的 性格は，当初の生検組織で疑われた未分化小細胞癌と， 基底細胞腺癌とを鑑別する際の典型的な所見といえるだ 万丂.

多くの場合，この腫瘍に対する治療は手術的に行われ る. 浸潤性増殖を示す反面，前述のごとく，核異型や細 胞異型はほとんど認められないなど，低悪性度とみなさ れていることから，放射線療法は効果的でないとする報 告もあるが7)，逆に効果的とする報告もみられる11).

Ellis ら ${ }^{3)}$ の報告に执いては，経過観察が行われた 25 例のらち，7 例で再発を認め，5ち 3 例は転移性病変を 示した. その 3 例のらち 2 例は所属リンパ節に, 1 例は 肺転移をきたしたものである。本邦の報告例では，報告 の時点で (術後 $1 \sim 3$ 年), 重見ら ${ }^{13)}$ の 1 例に 2 度の局 
所再発が報告されているのと, 新分類以前の大島ら ${ }^{14)}$ の例で脳扣よび肺への転移をきたしたもの以外に再発を 認めているものはない.

本症例は術後 3 年となる現時点で局所再発, 所属リン パ節特よび遠隔転移ともに認められず，良好な経過をた ぞっているが，今後とも慎重に経過観察を続けることが 必要であると考光られる.

\section{まとめ}

1.54歳男性の䫈下腺に原発した基底細胞腺癌の 1 例 を経験した。

2. 本症例の組織診断に括いて, 免疫組織化学的情報 が有用であった。

3 . 本疾患の疫学, 診断, 治療, 予後等に関し, 文献 的考察を行った.

本症例の病理学的診断に際し貴重なご意見を賜り, 免疫組織 化学標本の顕微鏡写真の使用をご許可くださった，川崎医科大 学病理学教室広川満良先生飞感謝いたします。

\section{参考文献}

1) Kleinsasser O and Klein HL : Basalzelladenome der Speicheldrüsen. Arch Klin Exp Ohren Nasen Kehlkopfheilkd $189: 302 \sim 316,1967$.

2) Seifert G, Brocheriou C, Cardesa A, et al : WHO international histological classification of tumors; tentative histological classification of salivary gland tumors. Path Res Pract 186 : 555 581, 1990.

3 ) Ellis GL and Wiscovitch JG : Basal cell adenocarcinomas of the major salivary glands. Oral Surg Oral Med Oral Pathol 69 : 461 469, 1990.

4 ) 吉田秀夫, 近藤康夫, 岡本正人, 他: 小唾液腺由来基底細 胞腺癌の 1 例. 日癌会51回総会記 : 333, 1992.

5 ) 森田章介, 柚木大和, 中嶋正博, 他 : 頓粘膜の小唾液腺に 発生した基底細胞腺癌と考えられた 1 症例. 頭頸部腫瘍 $20: 384,1994$.

6 ）二階宏昌, 小川郁子, 高田 隆, 他 : 小唾液腺基底細胞腺 癌の組織診断に関する検討. 日病会誌 $83: 172,1994$.
7 ）松塚 崇, 鹿野真人, 佐藤和則, 他: 小睡液腺由来の基底 細胞腺癌の一例. 耳鼻臨床 補83:108 112, 1995.

8 ) 楠 信也, 石田 武, 西村良彦, 他: 耳下腺原発の basal cell adenocarcinoma の 1 例. 日臨外 $57: 53 \sim 56,1996$.

9 ) 高橋伸彰, 八幡智裕, 美田佳壽彦, 他: 口蓋部に発生した 小唾液腺原発の基底細胞腺癌の 1 例. 口科誌 45: 567, 1996.

10）田中陽一, 宜保一夫, 小野田雅美, 他: 耳下腺に生じ細胞 像が腺様囊胞癌ときわめて類似した基底細胞腺癌の 1 例. 日臨細胞会誌 35補 $1: 209,1996$.

11）中川雅文, 竹澤裕之, 渡辺雅子, 他: 顎下腺に発生した基 底細胞腺癌の 1 例. 耳鼻 $43: 590 \sim 593,1997$.

12）樋口香里, 上田 大, 丸山 晋, 他: 耳下腺に発生した基 底細胞腺癌の 1 例. 耳喉頭頸 $69: 438 \sim 443,1997$.

13）重見英男, 須小 毅, 鈴木正志, 他 : 耳下腺基底細胞腺癌 の 2 症例. 口咽科 $11: 146,1998$.

14）大島 渉, 松岡秀樹, 斉藤 等, 他 : 唾液腺基底細胞腫の 1 例一混合腫瘍から独立させるべき疾患として一. 耳喉 $48:$ 105 109, 1973.

15）楊 光宗, 本田啓二, 久保伸夫, 他 : 悪性を伴った耳下腺 基底細胞腺腫の 1 例. 耳鼻臨床 $76: 2911 \sim 2916,1983$.

16）片桐 聡, 村上国孝, 松岡秀樹, 他 : 動眼神経麻瘏を呈し た上咽頭原発基底細胞腺腫の 1 例. 日赤医 $41: 207 \sim 210$, 1989.

17) Williams SB, Ellis GS and Auclair PL : Immunohistochemical analysis of basal cell adenocarcinoma. Oral Surg Oral Med Oral Path 75 : 64 69, 1993.

18) Raslan FW, Leonetti JP and Sawyer DR : Basal cell adenocarcinoma of the parotid gland; a case report with immuno-histochemical, ultrastructural findings and review of the literature. J Oral Maxillofac Surg $53: 1457 \sim 1462$, 1995.

19) Pisharodi LR : Basal cell adenocarcinoma of the salivary gland; diagnosis by fine needle aspiration cytology. Am J Clin Pathol 103 : 603 608, 1995.

$$
\left(\begin{array}{l}
\text { 原稿受付 : 平成 } 11 \text { 年 } 5 \text { 月 } 12 \text { 日 } \\
\text { 原稿採択 : 平成 } 11 \text { 年 } 7 \text { 月 } 7 \text { 日 } \\
\text { 別刷請求先 : 坪田 大 } \\
\text { 干 } 060-8543 \text { 札幌市中央区南 } 1 \text { 条西 } 16 丁 \text { 目 } \\
\text { 札幌医科大学耳鼻咽喉科学教室 }
\end{array}\right)
$$

